\title{
Role of MRI for Assessment of Anal Fistula
}

\author{
Dr. Pramod Shaha ${ }^{1}$, Dr. (Brig) K. Sahoo, Dr. Jainesh Dodia, Dr. Vinay Raj R, Dr. Shweta Bhairagond ${ }^{2}$ \\ Krishna Institute of Medical Sciences University
}

\begin{abstract}
The role of MRI in imaging perianal fistula is to outline all hidden tracts and define the relationship of the fistula to the anal sphincter. A detailed assessment of the anatomic relationship between the fistula and the anal sphincter complex allows surgeons to choose the best surgical treatment thus significantly reducing recurrence of the disease or possible secondary effects of surgery, such as fecal incontinence. MRI also help in delineating associated abscesses, horse shoe and secondary tract alerting the surgeon about the complex nature of the disease and providing an excellent road map prior to surgery. MRI is well tolerated, non-invasive, painless and not embarrassing for the patient, thus has been made it the modality of choice in evaluating perianal fistulas. Aim of the study was to determine the type, extent, associated abscesses and relations of perianal fistula with the anal sphincter complex. To obtain critical information with MRI for the surgical decision.
\end{abstract}

Keywords: MR: Magnetic resonance

\section{Introduction}

A fistula is defined as a pathologic tract connecting two hollow organs or one hollow organ and the skin, in the case of anal fistula, usually between the anal canal and perianal skin.

In 1988 Robinson et al postulated that, Infection of the anal glands and crypts is thought to be the cause of later fistula formation. The disease usually begins as an abscess and in chronic stages develops into a fistula in $60 \%$ of cases. ${ }^{(1)}$

The initiating event according to the ,cryptoglandular hypothesise in the formation of perianal fistulas is infection of the intersphincteric glands at the dentate line, which may then track down either the intersphincteric plane to the skin or may traverse both anal sphincter layers to enter the ischioanal fossa.

It is believed that gland infection results in an intersphincteric abscess if the draining duct becomes blocked by infected debris. This abscess may resolve by means of spontaneous drainage into the anal canal or may progress to an acute anorectal abscess, which is a common acute surgical emergency and is familiar to all general and coloproctologic surgeons. ${ }^{(2)}$

In 1991 as proposed by Fucini C. one stage treatment of anal abscesses and fistulae, generally consists of incision and drainage of the most fluctuant part of the abscess; however, this procedure does not pay due attention to the source of infection in the intersphincteric space, with the result that as many as $87 \%$ of patients with an acute abscess may subsequently develop a fistula. ${ }^{(3)}$

MRI is well tolerated, non-invasive, painless and not embarrassing for the patient, thus has been made it the modality of choice in evaluating perianal fistulas.

The role of imaging is to outline all hidden tracts and define the relationship of the fistula to the anal sphincter. A detailed assessment of the anatomic relationship between the fistula and the anal sphincter complex allows surgeons to choose the best surgical treatment thus significantly reducing recurrence of the disease or possible secondary effects of surgery, such as fecal incontinence. ${ }^{(4,5)}$

Pre-operative confirmation of fistula complexity has been shown to facilitate surgical planning of sphincter saving techniques and to reduce the incidence of unidentified sepsis, which is the leading cause of fistula recurrence.

\section{St James's University Hospital MR Imaging Classification of Perianal Fistulas:}

The MR imaging- based classification used in our institution, the St James's University Hospital classification, consists of five grades and relates the Parks surgical classification to anatomy seen at MR imaging in both axial and coronal planes.

Table 1: St James's University Hospital MR Imaging ${ }^{(6)}$ : Grade Description

\begin{tabular}{|c|c|}
\hline 0 & Normal appearance \\
\hline I & Simple linear intersphincteric fistula \\
\hline II & $\begin{array}{c}\text { Intersphincteric fistula with intersphincteric abscess or } \\
\text { secondary fistulous track }\end{array}$ \\
\hline III & Trans-sphincteric fistula \\
\hline IV & $\begin{array}{c}\text { Trans-sphincteric fistula with abscess or secondary track } \\
\text { within the ischioanal or ischiorectal fossa }\end{array}$ \\
\hline V & Supralevator and translevator disease \\
\hline
\end{tabular}

- Active fistula tract appears as a hypointense linear structure on T1-weightedimaging and hyperintense on T2-weighted imaging (best visualized with fat saturation) relative to muscle and enhances with IV contrast agent. Granulation tissue with increased vascularity is thought to account for the T2-weighted imaging hyperintensity and contrast enhancement. ${ }^{(7)}$

- Inactive tracts are also hypointense on T1-weighted imaging but lack the associated T2-weighted imaging hyperintensity and contrast enhancement.

- The internal opening can be described according to anterior-posterior and right left locations or according to the "anal clock" with the patient in the supine position. Most perianal fistulas arise at the dentate line posteriorly. ${ }^{(8)}$ Finally, the integrity of the levatorani should be scrutinized to assess for suprasphincteric or translevator disease. 


\section{International Journal of Science and Research (IJSR) \\ ISSN (Online): 2319-7064 \\ Index Copernicus Value (2013): 6.14 | Impact Factor (2014): 5.611}

Secondary tracts will have features similar to those of the primary tract, and their course should be defined relative to the sphincters, levator ani, and overlying skin. Perianal abscesses may occur anywhere along a fistula tract and typically have central hyperintense signal on T2-weighted imaging corresponding to pus with peripheral rim enhancement secondary to the fibrous wall and surrounding inflammation. Any tracts that cross the levatorani warrant careful evaluation ofthe pelvis to assess for a primary pelvic source.

MRI allows accurate assessment of associated abscesses, horse shoe and secondary tract alerting the surgeon about the complex nature of the disease and providing an excellent road map prior to surgery. ${ }^{(9,6,10)}$

On MR images, external anal sphincter (striated muscle) is clearly visualized on MRI. It is hypointense on T1W, T2W, and fat-suppressed T2W images, and is bordered laterally by the fat in the ischioanal fossa. The internal sphincter (smooth muscle) is hypointense on T1W and T2W TSE images and is relatively hyperintense on fat-suppressed $\mathrm{T} 2 \mathrm{~W}$ images. It shows enhancement on post-gadolinium T1W images. The coronal images depict the levatorani muscle, the identification of which is important to distinguish supralevator from infralevator infections.

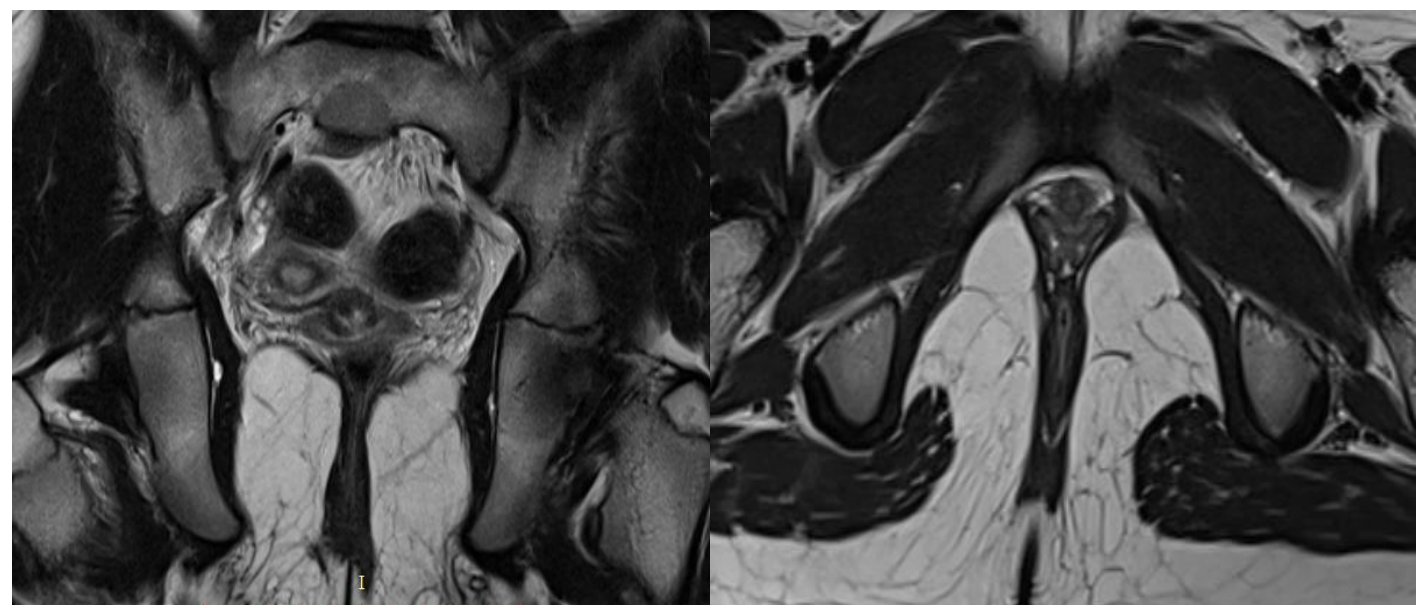

The treatment of fistulas requires surgery, associated with a significant prevalence of recurrence mainly due to two drawbacks $^{(11)}$

Firstly, inadequate preoperative findings of secondary tracts or abscess formation.

Secondly, the significant percent of these diseases persist or recur when the preoperative evaluation of fistulous tract is not done or right modality of surgery is not adopted or when the post-operative care is inadequate.

Successful surgical management of anal fistulas requires accurate preoperative assessment of the course of the primary fistulous track and the site of any secondary extension or abscesses. ${ }^{(12)}$

Magnetic resonance (MR) imaging has been shown to demonstrate accurately the perianal anatomy, methods for preoperative assessment and useful MR imaging protocols for this evaluation. The main idea behind preoperative workup was to overcome difficulties in the assessment of fistulous tracts which may lead to unsuccessful "blind" attempts at tract delineation during surgery and complications such as anal sphincter injury and a faecal incontinence. The goal of treatment of fistula-in-ano is eradication of sepsis without sacrificing continence. Confrontation of preoperative MRI results with operative findings was done. MR imaging is noninvasive, is highly accurate, and has low interobserver variability.

According to Lunniss PJ et al, MRI performed adequately should be regarded as the "gold standard" for preoperative assessment, replacing surgical examination under anesthetic (EUA) in this regard. ${ }^{(13)}$

\section{Aims and Objectives}

To assess the role of diagnostic accuracy of MRI perianal fistula.

MRI in determining the type, extent, associated abscesses and relations with the anal sphincter complex.

To obtain critical information with MRI for the surgical decision.

\section{Material and Methods}

Type of Study: Prospective study.

The study was conducted in the department of RadioDiagnosis, Krishna Hospital \& Medical Research Centre, Karad, Maharashtra. for a period of 22 months i.e. from Aug 2013 to July 2015. The study group included a total of 62 patients with perianal discharge through fistula with or without pain presenting in the department of General Surgery.

Prior to operation Perianal fistulas were classified according to the St. James University Hospital classification and MR findings were correlated with surgical findings. Surgery was performed in 60 out of total 62 patients.

\section{Inclusion Criteria}

- Patients visiting to Krishna Hospital surgical OPD with complains of discharge through fistula are further referred for preoperative evaluation. 


\section{International Journal of Science and Research (IJSR) \\ ISSN (Online): 2319-7064 \\ Index Copernicus Value (2013): 6.14 | Impact Factor (2014): 5.611}

- All patients with the clinical diagnosis of anal fistula who were scheduled for surgical exploration were considered candidates for inclusion.

\section{Exclusion Criteria}

- Patients having cardiac pacemaker or implants where MR could not be performed.

- Blind ending sinus tracts and submucosal fissures where not included in study group.

- Uncooperative patients in whom MRI could not be performed.

- Patients with prior surgery of Perianal fistula as true classification of fistula cannot be done due to disturbed anatomy after post-operative changes.

\section{Equipment Used}

Avanto Tim + Dot 1.5 Tesla Seimens Using Sense Body Coil (Receiver only Coil) \& phased array surface coils. Patients were scanned in a supine position with leg slightly apart. An important advantage of MR imaging in fistula evaluation is the ability to study the anal sphincter complex in any surgically relevant plane. For this reason, it is critical that imaging planes are correctly aligned with respect to the anal canal. The anal canal is tilted forward from the vertical by approximately $45^{\circ}$ in the sagittal plane; thus, straight axial and coronal images will not allow correct evaluation of the source and the fistulous track. Therefore, it is necessary to obtain oblique axial and coronal images oriented orthogonal and parallel to the anal canal, respectively. ${ }^{(7)} \mathrm{To}$ achieve the correct orientation, a sagittal fast spin-echo (FSE) T2-weighted sequence should be performed initially, providing an overview of the pelvis and showing the extent and axis of the anal canal. The correct orientation of the anal canal for MR imaging can be derived from this sequence, providing truly axial and coronal images along the long axis of the anal canal and enabling correct assessment of perianal fistulas. The levator plate and the entire perineum should be included to identify areas of sepsis and infected tracks that may lead to recurrence.
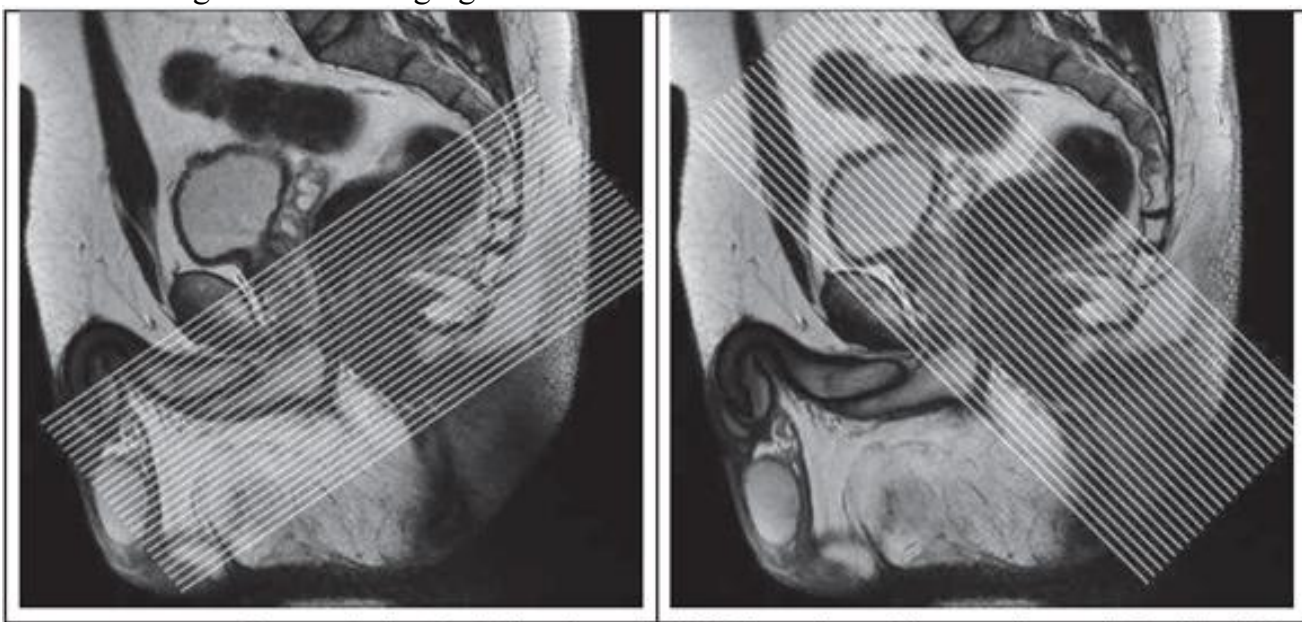

Suggested orientation for axial MR imaging of the anal canal. Sagittal T2weighted ımage through the midline is used to obtain images that are truly axial relative to the anal canal. Suggested orientation for coronal MR imaging of the anal canal. Coronal MR imaging is performed at $90^{\circ}$ relative to the axial plane to obtain images parallel to the long axis of the anal canal.

The most appropriate protocol that we have followed for this study at our institution for evaluation of perianal fistulas consists of the following sequences: Sagittal T2-weighted TSE, oblique axial T2-weighted TSE, Oblique coronal T2weighted TSE and oblique axial T1-weighted TSE. Evion capsule (vitamin E) was placed at the site of external opening of fistula.

The planes used are obliquely-axial and obliquely coronal relative to the pelvis, but these planes are truly orthogonal and parallel relative to the anal canal and thus suitable for correct evaluation of perianal fistulas. It is not appropriate to use the terms axial and coronal to refer to these planes; their use is not correct in terms of the orientation of the planes relative to the pelvis. Gadopentate-dimeglumine 0.1 $\mathrm{mmol} / \mathrm{kg}$ was used as contrast administered intravenously by hand. This is followed by obtaining oblique axial and oblique coronal fat-suppressed T1-weighted FSE with oriented perpendicular or parallel (in the case of the latter) to the long axis of the anal canal. 


\section{International Journal of Science and Research (IJSR) \\ ISSN (Online): 2319-7064 \\ Index Copernicus Value (2013): 6.14 | Impact Factor (2014): 5.611}

Table 2: Full details of the MR imaging parameters are given in the Table below

\begin{tabular}{|c|c|c|c|c|c|c|}
\hline Sequences & TR & $\mathrm{TE}$ & FOV & NSA & ST & MAT/REC \\
\hline T2W TSE SAG FS & 3000 & 90 & 400 & 3 & 5 & $768 / 768$ \\
\hline T2W TSE OCOR FS & 3000 & 90 & 400 & 3 & 5 & $768 / 768$ \\
\hline T2W TSE OTRA FS & 3000 & 90 & 400 & 3 & 5 & $768 / 768$ \\
\hline T1W TSE OTRA & 500 & 12 & 400 & 3 & 5 & $768 / 768$ \\
\hline $\begin{array}{l}\text { T1W TSE FS POST- } \\
\text { CONTRAST - } \\
\text { OTRA/COR }\end{array}$ & 500 & 12 & 400 & 3 & 5 & $768 / 768$ \\
\hline \multicolumn{7}{|c|}{$\begin{array}{l}\text { MR imaqinq protocol. T1W -T1 weighted, T2W - T2 weighted, FS - Fat } \\
\text { Saturated, TSE-Turbo Spin Echo, OTRA- Oblique Transverse, OCOR- oblique } \\
\text { Coronal, SAG - sagittal TR- Repetition Time, TE- Echo Time, FOV- Field of } \\
\text { View, NSA- Number of Signal Averages, MAT-Matrix, REC-Reconstruction, } \\
\text { ST: slice thickness }\end{array}$} \\
\hline
\end{tabular}

Surgical exploration was done in 60 out of 62 patients all the cases, with the aid of MRI observations and the peroperative findings were used to scrutinize the imaging results. Both internal and external openings were recorded as their position on anal clock and at their correct level in anal canal / rectum. Surgical findings were accepted as the gold standard and were recorded independently by the surgeon.

\section{Results}

Gender v/s Age Wise Distribution: It was observed that the maximum number of patients $(\mathrm{n}=62$ patients) who underwent this procedure were in the age group of $31-40$ years which comprised $40.32 \%$ of the series followed by $17.74 \%$ of the patients in the range of $41-50$ years. It is observed that males are $48(77.41 \%)$ and females are 14 $(22.58 \%)$ who underwent this study.

\begin{tabular}{|c|c|c|}
\hline Perianal fistulas & Males & Females \\
\hline Buchanan et al $^{(14)}$ & $71.1 \%$ & $28.85 \%$ \\
\hline Al-Khawari HA et al $^{(15)}$ & $80.7 \%$ & $19.2 \%$ \\
\hline Waniczek et al $^{(16)}$ & $78.5 \%$ & $21.5 \%$ \\
\hline Present Study $^{2}$ & $77.41 \%$ & $22.58 \%$ \\
\hline
\end{tabular}

The result of present study correlates well with studies done by Buchanan et al, Al-Khawari HA et al and Waniczek et al. ${ }^{(14,15,16)}$

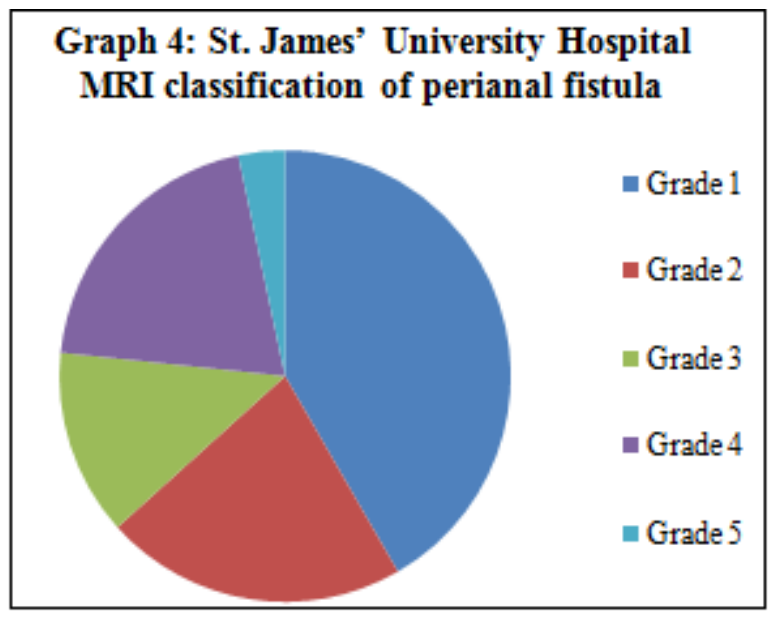

In our study, Grade 1 perianal fistula was the commonest condition accounting for 24 cases $(40 \%)$ followed by Grade 2and Grade 4 accounting for 14 and 12 cases respectively.

\section{Distribution of simple \& Complex Perianal Fistulas} $(\mathrm{n}=60)$

\begin{tabular}{|c|c|c|}
\hline Type of Fistulas & Number & \% of Distribution \\
\hline Simple & 32 & 53.33 \\
\hline Complex & 28 & 46.66 \\
\hline Total No of Fistulas & 60 & 100 \\
\hline
\end{tabular}

Occurrence of the complex perianal fistulas (70\%) appears predominates than the simple perianal fistulas $(30 \%)$.

Kuster GG. Et al explained the relationship of anal glands and lymphatics, there will usually be an internal enteric opening in the anal canal at the level of the dentate line, at the original site of the duct draining the infected gland. In most cases this is at the 6-o clock position, because anal glands are more abundant posteriorly, explained by (radial positions around the anus are referenced with respect to a clock face with 12 oeclock being directly anterior. ${ }^{(8)}$ Fistulas are classified according to the route taken by this "primary tract" that links the internal and external openings, some more tortuous than others, and by penetrating and involving the muscles of the anal sphincter and surrounding tissues to a variable degree. In 1934, Milligan and Morgan stressed the importance of the "anorectal ring" (anatomically the puborectalis muscle) and categorized fistulas as those that entered the anal canal above or below this structure, warning that postoperative incontinence was highly likely if high fistulas were surgically divided without due attention. ${ }^{(17)}$

Location of internal opening on MRI. Internal opening was seen in 60 patients on MRI and surgical correlation was proved in 58 patients.

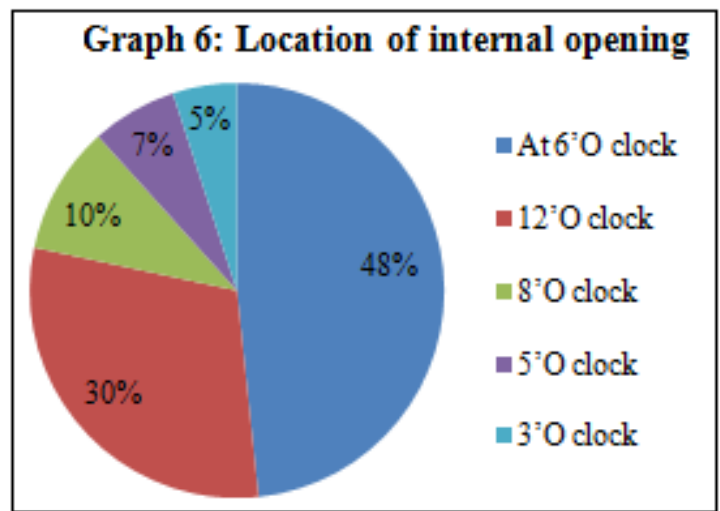




\section{International Journal of Science and Research (IJSR) \\ ISSN (Online): 2319-7064 \\ Index Copernicus Value (2013): 6.14 | Impact Factor (2014): 5.611}

We then describe all MR imaging-based grading system for perianal fistulas (the St Jameses University Hospital classification and Park classification) that has been validated by surgically proved cases with documented long-term outcome. $^{(7)}$

Table 17: Distribution of Cases According to the Type of Fistulas

\begin{tabular}{|c|c|c|c|c|c|}
\hline & $\begin{array}{c}\text { Total } \\
\text { patient } \\
\text { s }\end{array}$ & $\begin{array}{c}\text { Intersphincter } \\
\text { ic }\end{array}$ & $\begin{array}{c}\text { Transsphincter } \\
\text { ic }\end{array}$ & $\begin{array}{c}\text { Supralevato } \\
\text { r/ } \\
\text { Translevato } \\
\text { r }\end{array}$ & $\begin{array}{c}\text { Un } \\
\text { classifie } \\
\text { d }\end{array}$ \\
\hline $\begin{array}{c}\text { Baska } \\
\text { n et al } \\
(18)\end{array}$ & 136 & $95(69.9 \%)$ & $33(24.2 \%)$ & $2(1.5 \%)$ & $6(4.4 \%)$ \\
\hline $\begin{array}{c}\text { Morris } \\
\text { et al } \\
(6)\end{array}$ & & $70 \%$ & $20 \%$ & & \\
\hline $\begin{array}{c}\text { Criado } \\
\text { et al } \\
(7)\end{array}$ & 178 & $77(43.2 \%)$ & $88(49.44 \%)$ & $13(7.3 \%)$ & 0 \\
\hline $\begin{array}{c}\text { Presen } \\
\text { t study }\end{array}$ & 60 & $38(63.33 \%)$ & $20(33.33 \%)$ & $2(3.33 \%)$ & 2 \\
\hline
\end{tabular}

The path of least resistance for festering intersphincteric infection creates an intersphincteric fistula; this type of fistula composed $63.33 \%$ of cases. However, some truculent fistulas can cross the external sphincter and reach the ischioanal fossa results in a transsphincteric fistula, which composed $33.33 \%$ of cases. Other fistulas may spread upward in the intersphincteric space and arch over the puborectalis muscle, where they must cross the levator plate to reach the perianal skin. This type, the Supralevator / Translevator fistula, composed $3.33 \%$ of cases.

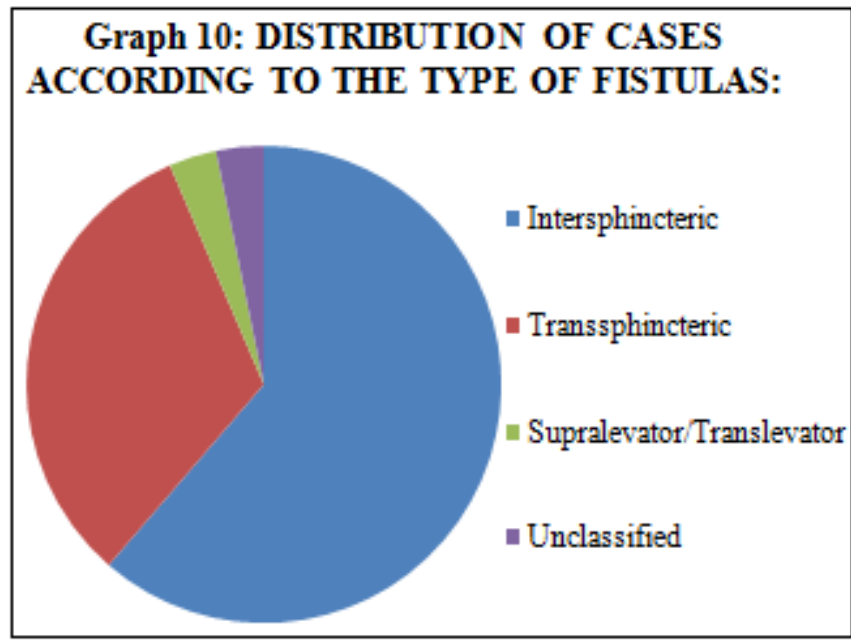

Table 18: Grading of Fistulas According to the St. Jamese ${ }^{\text {'s }}$ University Hospital Mr Imaging Classification

\begin{tabular}{|c|c|c|c|c|c|c|c|}
\hline & Total no. of patient & Grade 1 & Grade 2 & Grade 3 & Grade 4 & Grade 5 & Un-classified \\
\hline Baskan et al (18) & 136 & $70(51.5 \%)$ & $25(18.4 \%)$ & $16(11.7 \%)$ & $17(12.35)$ & $2(1.5 \%)$ & $6(4.4 \%)$ \\
\hline Criado J (7) & 178 & $44(24.7 \%)$ & $33(18.5 \%)$ & $43(24.2 \%)$ & $45(25.3 \%)$ & $13(7.3 \%)$ & 0 \\
\hline Present study & 60 & $24(40 \%)$ & $14(23.33 \%)$ & $8(13.3 \%)$ & $12(20 \%)$ & $2(3.3 \%)$ & 2 \\
\hline
\end{tabular}

Using the classification of St. James University Hospital, the fistulas were $11(33.3 \%)$ simple intersphincteric(Grade I), $4(12.1 \%)$ intersphincteric with abscess or secondary tract(Grade II), 7(21.2\%) transsphincteric(Grade III), $8(24.2 \%)$ transsphincteric with abscess or secondary tract(Grade IV) and 3(9\%) supralevator and translevator(Grade V).

Results of our study were consistent with study by Morris et $\mathrm{al}^{(6)}$, noted in his study that $70 \%$ of all patients were of intersphincteric type, while transsphincteric fistulas contributed $20 \%$ of the total.

Intersphincteric fistulas accounted for $45 \%$ of cases in the study of Parks et $\mathrm{al}^{(19)}$ and represented the most common of the four categories.

OzdilBaskan et $\mathrm{al}^{(18)}$, also concluded in his retrospective study that $69.9 \%$ of all Perianal fistulas were of intersphincteric type.

Complex fistulas are often associated with recurrent fistulas due to inadequate preoperative workup. In our study this hidden secondary tracts and abscesses where dissected and guided during surgery.

Table 19: Distribution of Primary Tracts, Abscesses, Secondary Tracts, Horseshoe extension and internal openings (the column "False Negative for Surgery represents the additional information) (Total fistulas $\mathrm{N}=60$ including multiple fistulas excluding submucosal fissures $=2$ ):

\begin{tabular}{|c|c|c|c|c|}
\hline MRI Findings & $\begin{array}{c}\text { True } \\
\text { positive }\end{array}$ & $\begin{array}{c}\text { False } \\
\text { positive }\end{array}$ & $\begin{array}{c}\text { False } \\
\text { negative }\end{array}$ & $\begin{array}{c}\text { True } \\
\text { negative }\end{array}$ \\
\hline Primary tract* & 60 & 00 & 00 & 02 \\
\hline Abscess & 09 & 00 & 00 & 51 \\
\hline Secondary tracts & 26 & 03 & 00 & 34 \\
\hline Horseshoeing & 02 & 00 & 00 & 58 \\
\hline Internal openings* & 60 & 02 & 00 & 02 \\
\hline Supralevator extension & 02 & 00 & 00 & 58 \\
\hline
\end{tabular}

*For primary tract \& Internal opening: $\mathrm{N}=62$ 


\section{International Journal of Science and Research (IJSR) \\ ISSN (Online): 2319-7064}

Index Copernicus Value (2013): 6.14 | Impact Factor (2014): 5.611

Table 20: Surgical correlation of MRI Findings Based on first table

\begin{tabular}{|c|c|c|c|c|c|}
\hline MRI Findings & Sensitivity & Specificity & PPV & NPV & Accuracy \\
\hline Primary tract & $100 \%$ & $100 \%$ & $100 \%$ & $100 \%$ & $100 \%$ \\
\hline Abscess & $100 \%$ & $100 \%$ & $100 \%$ & $100 \%$ & $100 \%$ \\
\hline Secondary tracts & $89.66 \%$ & $100 \%$ & $100 \%$ & $91.89 \%$ & $95.38 \%$ \\
\hline Horseshoeing & $100 \%$ & $100 \%$ & $100 \%$ & $100 \%$ & $100 \%$ \\
\hline Internal openings & $96.77 \%$ & $100 \%$ & $100 \%$ & $50 \%$ & $86.69 \%$ \\
\hline Supralevator extension & $100 \%$ & $100 \%$ & $100 \%$ & $100 \%$ & $100 \%$ \\
\hline
\end{tabular}

Table 21: Correlation between MRI Findings and Surgical Findings

\begin{tabular}{|c|c|c|c|}
\hline Study & $\begin{array}{c}\text { Total } \\
\text { patients }\end{array}$ & $\begin{array}{c}\text { Surgical findings } \\
\text { correlates with MRI }\end{array}$ & Accuracy \\
\hline Al-Khawari HA et al $^{(15)}$ & 16 & 15 & $93.7 \%$ \\
\hline Perini L et al $^{(20)}$ & 17 & 15 & $88.2 \%$ \\
\hline Hutan et al $^{(21)}$ & 14 & 12 & $85.7 \%$ \\
\hline Spencer ja et al $^{(6)}$ & 42 & 37 & $88 \%$ \\
\hline Mullen r et al $^{(22)}$ & 40 & 34 & $85 \%$ \\
\hline Manar T Alaat El Essawy $^{(23)}$ & 56 & 52 & $\mathrm{P}=0.003$ significant \\
\hline Present study & 60 & 57 & $95 \%$ \\
\hline
\end{tabular}

To preserve continence, accurate presurgical definition of the relationship of the fistulous track to the anal sphincters is of great importance before performance of any sphincterinterrupting procedure. The information obtained with MR imaging appears to be a more powerful predictor of postoperative outcome than the information gained from surgical exploration. ${ }^{(6,24)}$

Table 16: Accuracy of MRI sequences in detecting fistulous tract

\begin{tabular}{|c|c|c|c|c|c|c|c|}
\hline & $\begin{array}{c}\text { Primary } \\
\text { fistulous tract }\end{array}$ & Abscess & $\begin{array}{c}\text { Secondary } \\
\text { tracts/ } \\
\text { ramifications }\end{array}$ & $\begin{array}{l}\text { Horse shoe } \\
\text { component }\end{array}$ & $\begin{array}{c}\text { Internal } \\
\text { opening } \\
\text { seen }\end{array}$ & $\begin{array}{c}\text { Supralevator } \\
\text { extension }\end{array}$ & $\begin{array}{l}\text { Overall \% } \\
\text { accuracy }\end{array}$ \\
\hline T1WFSE Axial and coronal oblique & $\begin{array}{c}57 / 60 \\
95 \%\end{array}$ & $\begin{array}{c}6 / 9 \\
66.66 \%\end{array}$ & $\begin{array}{c}15 / 26 \\
57.69 \%\end{array}$ & $\begin{array}{c}1 / 2 \\
50 \%\end{array}$ & $\begin{array}{c}57 / 60 \\
95 \%\end{array}$ & $\begin{array}{c}1 / 2 \\
50 \%\end{array}$ & $69.05 \%$ \\
\hline $\begin{array}{c}\text { T2WFSE } \\
\text { Axial, coronal }\end{array}$ & $\begin{array}{c}57 / 60 \\
95 \% \\
\end{array}$ & $\begin{array}{c}7 / 9 \\
77.77 \% \\
\end{array}$ & $\begin{array}{c}17 / 26 \\
65.38 \% \\
\end{array}$ & $\begin{array}{c}2 / 2 \\
100 \% \\
\end{array}$ & $\begin{array}{c}56 / 60 \\
93.33 \% \\
\end{array}$ & $\begin{array}{c}2 / 2 \\
100 \% \\
\end{array}$ & $88.58 \%$ \\
\hline T2WFSE sagittal & $\begin{array}{c}52 / 60 \\
86.66 \%\end{array}$ & $\begin{array}{c}6 / 9 \\
66.66 \% \\
\end{array}$ & $\begin{array}{c}13 / 26 \\
50 \%\end{array}$ & $\begin{array}{c}1 / 2 \\
50 \%\end{array}$ & $\begin{array}{c}52 / 60 \\
86.66 \% \\
\end{array}$ & $\begin{array}{c}1 / 2 \\
50 \% \\
\end{array}$ & $64.99 \%$ \\
\hline $\begin{array}{c}\text { Fat suppressed T1WFSE Plain, Axial and } \\
\text { coronal }\end{array}$ & $\begin{array}{c}59 / 60 \\
98.33 \% \\
\end{array}$ & $\begin{array}{c}7 / 9 \\
77.77 \% \\
\end{array}$ & $\begin{array}{c}18 / 26 \\
69.23 \% \\
\end{array}$ & $\begin{array}{c}1 / 2 \\
50 \% \\
\end{array}$ & $\begin{array}{c}56 / 60 \\
93.33 \% \\
\end{array}$ & $\begin{array}{c}2 / 2 \\
100 \% \\
\end{array}$ & $81.44 \%$ \\
\hline T2WFSFSE Axial and coronal & $\begin{array}{l}60 / 60 \\
100 \% \\
\end{array}$ & $\begin{array}{c}9 / 9 \\
100 \% \\
\end{array}$ & $\begin{array}{c}25 / 26 \\
96.15 \% \\
\end{array}$ & $\begin{array}{c}2 / 2 \\
100 \% \\
\end{array}$ & $\begin{array}{c}58 / 60 \\
96.66 \% \\
\end{array}$ & $\begin{array}{c}2 / 2 \\
100 \% \\
\end{array}$ & $98.80 \%$ \\
\hline T1WFSFSE Post contrast coronal and axial & $\begin{array}{l}60 / 60 \\
100 \% \\
\end{array}$ & $\begin{array}{c}9 / 9 \\
100 \% \\
\end{array}$ & $\begin{array}{l}26 / 26 \\
100 \% \\
\end{array}$ & $\begin{array}{c}2 / 2 \\
100 \% \\
\end{array}$ & $\begin{array}{c}59 / 60 \\
98.33 \% \\
\end{array}$ & $\begin{array}{c}2 / 2 \\
100 \% \\
\end{array}$ & $99.72 \%$ \\
\hline
\end{tabular}

\section{Discussion}

Magnetic resonance (MR) imaging has been shown to demonstrate accurately the perianal anatomy, methods for preoperative assessment and useful MR imaging protocols for this evaluation. The main idea behind preoperative workup was to overcome difficulties in the assessment of fistulous tracts which may lead to unsuccessful "blind" attempts at tract delineation during surgery and complications such as anal sphincter injury and a faecal incontinence. The goal of treatment of fistula-in-ano is eradication of sepsis without sacrificing continence. Confrontation of preoperative MRI results with operative findings was done. MR imaging is noninvasive, is highly accurate, and has low interobserver variability.

Table 23: Comparison of Sensitivity and specificity of our study with international literature

\begin{tabular}{|c|c|c|c|c|c|}
\hline & $\begin{array}{c}\text { Beckingham } \\
\text { et al }^{(25)}\end{array}$ & $\begin{array}{l}\text { Regina } \\
\text { et } \mathrm{al}^{(10)}\end{array}$ & $\begin{array}{c}\text { Jaime de } \\
\text { Miguel Criado } \\
\text { et al }^{(7)}\end{array}$ & $\begin{array}{l}\text { Manar T Alaat El } \\
\text { Essawy }^{(23)}\end{array}$ & Our study \\
\hline Sensitivity & $97 \%$ & $100 \%$ & $97 \%$ & \multirow{2}{*}{$\begin{array}{l}\mathrm{P}=0.003 \\
\text { significant }\end{array}$} & $95 \%$ \\
\hline Specificity & $100 \%$ & $86 \%$ & $100 \%$ & & $\begin{array}{l}100 \% \\
P=0.0026\end{array}$ \\
\hline
\end{tabular}

Because fistulas tracks encircle variable amount of the sphincter complex. Subsequent study by Beckingham IJ et al, suggested that MRI is more sensitive than even surgical exploration of the tract. ${ }^{(25)}$
Surgical treatment is dictated by the location of the internal and external openings and the course of the fistula.

The most important anatomical points for the surgeon were internal opening location which was described in clock that MR imaging could depict more extensions and/or associated 


\section{International Journal of Science and Research (IJSR) \\ ISSN (Online): 2319-7064 \\ Index Copernicus Value (2013): 6.14 | Impact Factor (2014): 5.611}

findings than could be gained from direct surgical exploration without preoperative imaging. So, additional information that can be obtained from preoperative MR imaging will improve the surgical results, especially in patients with complex high grade fistulas. ${ }^{(26)}$

It is important to find the exact site of internal opening otherwise there will be inadequate treatment and rate of recurrence of fistula would be high.

Present study has reported sensitivity of $95 \%$, specificity of $100 \%$ and positive predicted value of $100 \%$ in detecting internal openings.

Coronal and axial T2WFSFSE showed an accuracy of $96.6 \%$ and axial and coronal post contrast T1WFSFSE showed the highest accuracy of $98.3 \%$ in detection of internal opening.

This correlates well with previous study by Beets- Tan et $\mathrm{al}^{(10)}$ who reported sensitivity of $96 \%$, specificity of $90 \%$ and PPV of $90 \%$. Similarly Barker et al ${ }^{(27)}$ reported that sensitivity of MRI is $80 \%$ in detecting internal openings. Study by Singh et $\mathrm{al}^{(28)}$ reported sensitivity of $95.83 \%$, specificity of $80 \%$ and PPV of $97.87 \%$.

Study done by Holzer b et al - in 21 of 28 , internal opening correctly indicated by MRI-75\%accuracy. ${ }^{(29)}$

Stoker et al, concluded in their study that internal opening was successfully seen by FS-CE-T1W, T2W and STIR images this was in good correlation with surgical findings. ${ }^{(30)}$

Perianal fistula had internal enteric opening in the anal canal at the level of the dentate line. In most cases this is at the 6o celock position, because anal glands are more abundant posteriorly, postulated by Kuster GG. Et al. ${ }^{(8)}$

In 2 patients, MRI was not able to distinguish clearly the internal sphincter and anal mucosa therefore the site of internal opening was inferred by the proximity of the tract within the intersphincteric space. According to Halligan et al, area of maximum intersphinctric sepsis is the probable site of internal opening. An internal opening was considered correctly identified when it was at the correct level in the anal canal and was within the correct quadrant. ${ }^{(30)}$

Primary tract was identified correctly in all 60 patients. Thus sensitivity for detection of primary tract is $100 \%$. Initial reports by Lunniss et $\mathrm{al}^{(27)}$, suggested a concordance rate of $86 \%$ to $88 \%$.Later studies by Beets- Tan et al ${ }^{(10)}$ are describing up to $100 \%$ sensitivity for detecting and grading the primary tract.

Secondary tracts/Ramifications were detected on surgery in total 60 patients and MRI could correctly identify all the secondary tracts in 57 patients. MRI has a sensitivity of $89.6 \%$, specificity of $100 \%$, positive predicted value of $100 \%$ and negative predicted value of $91.8 \%$ in correctly detecting secondary tracts.

Fallacies of MRI in detecting three patient was found. It was later found on review MRI in the light of surgical notes. It was partly healed tract and reveal less bright signal on T2WI and less enhancement on post contrast study. T2WFSFSE Axial and coronal and post contrast T1WFSFSE showed highest accuracy of $96.15 \%$ and $100 \%$ respectively in detection of secondary tracts.

Our study finding are similar to study by Mahjoubi et $\mathrm{al}^{(22)}$ who reported sensitivity and specificity of 80 and $100 \%$ respectively. Singh et $\mathrm{al}^{(28)}$ reported sensitivity of $93.75 \%$, specificity of $94.12 \%$, positive predicted value of $88.24 \%$ and negative predicted value of $96.97 \%$.

MRI correctly identified abscess in all 9 cases with correct establishment of their relation to levatorani and puborectalis muscle. MRI was found to have a sensitivity of $100 \%$, specificity of $100 \%$, positive predicted value of $100 \%$ and negative predicted value of $100 \%$ in correctly detecting abscess. Previous studies done by Beets- Tan et al and Mahjoubi et al reported a similar high sensitivity and specificity of $96 \%$ and $80 \%$ respectively. ${ }^{(10,22)}$

In evaluation of Abscess, T2WFSFSE Axial and coronal and post contrast T1WFSFSE revealed accuracy of $100 \%$ in detection of abscess.

While coronal planes were better in detection and evaluation of full extent of ischioanal and ischiorectal abscesses. Study done by KulvinderSinghetal ${ }^{(28)}$ MRI correctly identified the abscess in seven out of eight cases in his study.

Horseshoe type of fistula is a type of secondary tract with extension in horizontal plane on either side of midline. In our study MRI was found to have a sensitivity of $100 \%$, specificity of $100 \%$, positive predicted value of $100 \%$ and negative predicted value of $100 \%$ in detecting horseshoe shaped fistulas.

It correlates well with previous study by Beets- Tan et al who reported sensitivity, specificity and PPV of $100 \%$ and study by Barker et al who reported sensitivity of $97 \%$. $^{(10,27)}$

Coronal and axial T2WFSFSE and coronal and axial Post contrast T1WFSFSE both showed an accuracy of $100 \%$ in detection of horse shoe component and supralevator extension.

Study done by Rania E. Mohamed et al, showed 100\% accuracy of axial and coronal post contrast T1WFSFSE in the detection of Horse shoe feature. ${ }^{(21)}$

MRI classification of Perianal Fistulae has been significantly associated with clinical outcome. MRI grades vary between satisfactory and unsatisfactory outcomes.

In our study showed that both axial and coronal planes were found important and complementary to each other in complete work up for fistulas.

Supralevator disease was better visualized with coronal planes, while evaluation of primary tract internal opening, intersphincteric abscesses, intersphincteric $\mathrm{v} / \mathrm{s}$ transphincteric fistula was better visualized on axial planes. Unenhanced $\mathrm{T} 1 \mathrm{~W}$ images provide an excellent anatomic 


\section{International Journal of Science and Research (IJSR) ISSN (Online): 2319-7064 \\ Index Copernicus Value (2013): 6.14 | Impact Factor (2014): 5.611}

over view of the sphincter complex, levator plate and ischiorectal fossa.

Simple sub mucosal intersphincteric or low transsphincteric tracts affecting the distal third of the anal canal can be treated with fistulotomy without significant effect on continence. In cases of higher or complex fistulas retention of continence is a problem. Finally MR imaging guided surgery of anal fistula is feasible. Use of MRI imaging prevents incomplete procedures or surgery. MR imaging may become particularly useful in surgery of recurrent or complex anal fistulas and may lead to fewer recurrences.

Our study results showed that preoperative MR imaging helps surgeons to identify all secondary extensions of a complex fistula. The largest additional value was seen in the detection of supralevator abscesses and horseshoe fistulas. Secondary extensions are easily missed above the pelvic floor and in patients with multiple extensions. It is likely that the additional information obtained from MR imaging will improve the surgical results in patients with complex fistulas.

Recommended from study and limitations that MRI sequences such as diffusion weighted and MIP (maximum intensity projection) was not used in our study due to busy schedule of the equipment.

So further studies by using diffusion weighted and MIP are recommended from our work.

\section{Conclusion}

MR imaging has emerged as the imaging technique of choice for preoperative evaluation of perianal fistulas, providing high-spatial-resolution MR imaging is accurate for detecting anal fistulas and classifying according to St' James classification. MR imaging is noninvasive, is highly accurate, and has low interobserver variability. MRI proved to be rapid and noninvasive means of presurgical assessment. MRI evaluation of perianal fistula is helpful in preoperative workup due to its excellent soft tissue contrast, operator independence, multiplanar capabilities and superior field of view (FOV).

MR imaging provides precise definition of the fistulous track, along with its relationship to pelvic structures, and allows identification of secondary fistulas or abscesses.

Radiologists should be familiar with the anatomic and pathologic findings of perianal fistulas and classify them using the St James 's University Hospital MR imaging-based grading system. In this way, appropriate surgical management can be planned and recurrences can be prevented.

Active fistulous tracts, extensions and abscesses appears as high signal on T2W. Sphincter complex and muscles reveal low signal on $\mathrm{T} 1 \mathrm{w}$ images. Chronic fistulas and scar do not enhance with Gadolinium and reveal low signal on T1w and $\mathrm{T} 2 \mathrm{w}$ images. Literature are suggesting that Diffusion weighted and MIP (maximum intensity projection) images which can be used to identify such notorious fistula.
Overall accuracy of T1WFSFSE sequence and T2WFSFSE was $99.72 \%$ and $98.80 \%$ respectively in identifying and classifying perianal fistulae for preoperative workup.

Both Contrast enhanced axial and coronal fat suppressed post contrast (T1WFSFSE) and Axial and coronal T2WFSFSE sequences showed a highly significant correlation with findings on surgery.

Excellent agreement of preoperative MRI findings with operative findings was seen in our study.

\section{References}

[1] Robinson AMJr, DeNobile JW Anorectal abscess and fistula-in-ano. J Natl Med Assoc 1988;80(11):12091213.

[2] Buchan R, Grace RH. Anorectal suppuration: the results of treatment and the factors influencing the recurrence rate. Br J Surg 1973;60:537-540.

[3] Fucini C. One stage treatment of anal abscesses and fistulae. A clinical appraisal on the basis of two different classifications. Int J Colorectal Dis 1991;6:1216.

[4] Beckingham IJ, Spencer JA, Ward J, Dyke GW, et al. Prospective evaluation of dynamic contrast enhanced magnetic resonance imaging in the evaluation of fistula inano. Br J Surg 1996;83(10):1396-8.

[5] Buchanan G, Halligan S, Williams A, et al. Effect of MRI on clinical outcome of recurrent fistula-in-ano. Lancet 2002;360 (9346):1661-2].

[6] Morris J, Spencer JA, Ambrose NS. MR imaging classification of perianal fistulas and its implications for patient management. Radiographics 2000;20:623-35.

[7] de Miguel Criado J, del Salto LG, Rivas PF, del Hoyo LF, et al. MR Imaging Evaluation of Perianal Fistulas: Spectrum of Imaging Features. RadioGraphics 2012; 32(1):175-94.

[8] Kuster GG. Relationship of anal glands and lymphatics. Dis Colon Rectum 1965;8:329-332].

[9] Halligan S, Stoker J. Imaging of fistula in ano. Radiology 2006;239:18-33.

[10] Beets-Tan Regina G, Beets GL, van der Hoop AG, Kessels AG, et al. Preoperative MR imaging of anal fistulas: Does it really help the surgeon? Radiology. 2001 Jan;218(1):75-84.

[11]Lilius HG. Fistula-in-ano, an investigation of human foetal anal ducts and intramuscular glands and a clinical study of 150 patients. ActaChirScandSuppl 1968;383:788

[12] Seow-Choen, Phillips RK. Insights gained from the management of problematical anal fistulae at St. Markes hospital, 1984-88. Br J Surg 1991;78(5):539-41.

[13] Lunniss PJ, Phillips RKS. Anatomy and function of the anal longitudinal muscle. Br J Surg 1992;79:882-884.

[14] Buchanan GN, Halligan S, Bartram CI, Williams AB, et al. Clinical examination, endosonography, and MR imaging in preoperative assessment of fistula in ano: comparison with outcome-based reference standard. Radiology 2004;233(3):674-681.

[15] Al-Khawari HA1, Gupta R, Sinan TS, Prakash B, et al. Role of magnetic resonance imaging in the assessment 


\section{International Journal of Science and Research (IJSR) \\ ISSN (Online): 2319-7064 \\ Index Copernicus Value (2013): 6.14 | Impact Factor (2014): 5.611}

of perianal fistulas. Med PrincPract. 2005 JanFeb;14(1):46-52.

[16] DariuszWaniczek, Tomasz Adamczyk, Jerzy Arendt, EwaKluczewska, et al. Usefulness assessment of preoperative MRI fistulography in patients with perianal fistulas Pol J Radiol, 2011; 76(4): 40-44

[17] Milligan ET, Morgan CN. Surgical anatomy of the anal canal with special reference to anorectal fistulae. Lancet 1934;2:1213-1217.

[18] OzdilBaskan, Mustafa Koplay, MesutSivri, and CengizErol. Our Experience with MR Imaging of Perianal Fistulas. Pol J Radiol. 2014; 79: 490-7.

[19] Parks AG, Gordon PH, Hardcastle JD. A classification of fistula-in-ano. Br J Surg 1976;63:1-12.

[20] Perini L, Marcon M, Bidoli L, Fabris G, et al. Magnetic resonance in the assessment of perianal fistula. Radiol Med. 1995 May;89(5):637-42.

[21] Rania E. Mohamed, Dina M. Abo-Sheisha et al. Role of Magnetic resonance imaging in pre-operative assessment of ano-rectal fistula. The Egyptian Journal of Radiology and Nuclear Medicine 2014; 45,35-47.

[22] Mahjoubi B, HaizadchKharazi H, Mirzaei R, Moghimi A, et al. Diagnostic accuracy of body coil MRI in describing the characteristics of perianal fistulas. Colorectal Dis. 2006 Mar;8(3):202-7.

[23] Alaat El Essawy MT, Magnetic Resonance Imaging in Assessment of Anorectal Fistulae and its Role in Management. J Gastroint Dig Syst 2013; 3: 139.
[24] Chapple KS, Spencer JA, Windsor AC, Wilson D, et al. Prognostic value of magnetic resonance imaging in the management of fistula-in-ano. Dis Colon Rectum 2000;43(4):511-516.

[25] Beckingham IJ, Spencer JA, Ward J, Dyke GW, et al. Prospective evaluation of dynamic contrast enhanced magnetic resonance imaging in the evaluation of fistula inano. Br J Surg 1996;83(10):1396-8.

[26] Mahmoud E, Eid M, Mansy H, Matarawy K, Wally M Preoperative MRI of perianal fistula: Is it really indispensable? Can it be deceptive?. Alexandria Journal of Medicine 2013; 49: 133-144.

[27] Barker PG, Lunniss PJ, Armstrong P, Reznek RH, et al. Magnetic resonance imaging of fistula-in-ano: technique, interpretation, and accuracy. ClinRadiol 1994; 49(1):7-13.

[28] Singh K, Singh N, Thukral C, Singh KP, et al. Magnetic resonance imaging (MRI) evaluation of perianal fistulae with surgical correlation. J ClinDiagn Res. 2014 Jun;8(6):RC01-4.

[29] Holzer B, Rosen HR, Urban M, Anzböck W, et al. Magnetic resonance imaging of perianal fistulas: predictive value for Parks classification and identification of the internal opening. Colorectal Dis. 2000 Nov 17;2(6):340-5.

[30] Halligan S, Stoker J. Imaging of fistula in ano. Radiology 2006;239:18-33.
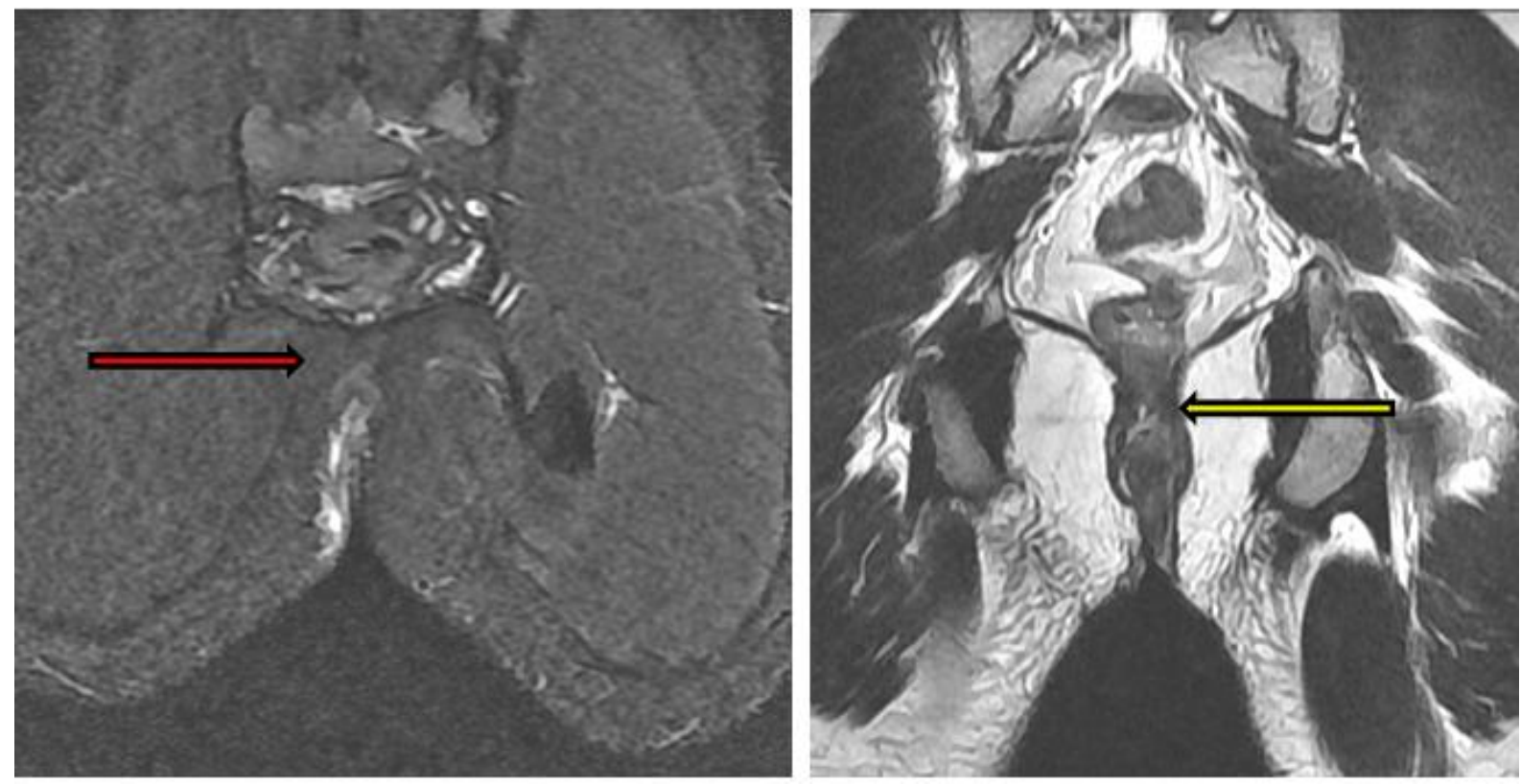

Intersphincteric fistula and internal opening

Right side Red arrow: 6'0 Clock right lateral and Left side Yellow arrow 3'0 Clock Left lateral

Figure 1: Internal Opening 


\section{International Journal of Science and Research (IJSR)}

ISSN (Online): 2319-7064

Index Copernicus Value (2013): 6.14 | Impact Factor (2014): 5.611

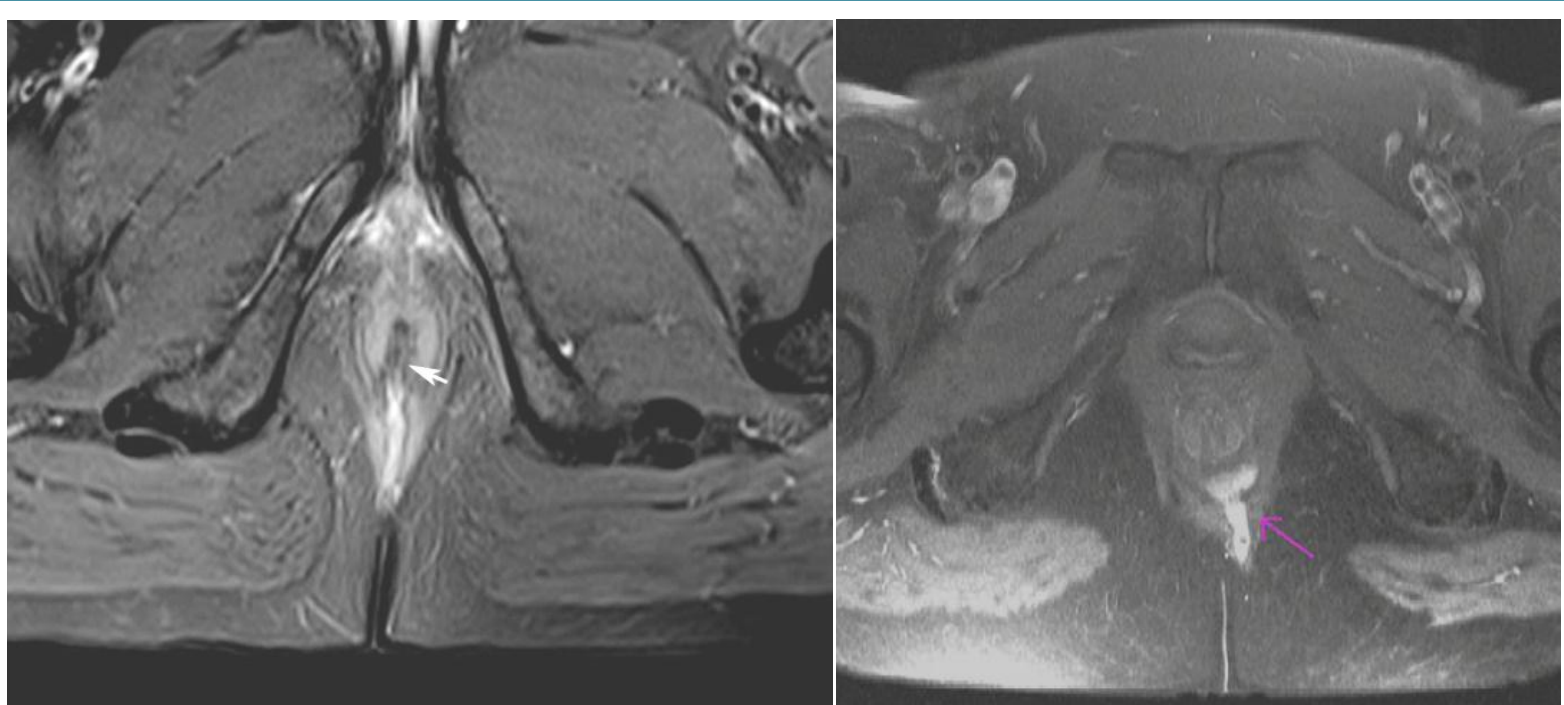

Figure 2: Red arrow: Grade III Transphincteric and internal opening (white arrow) at $6^{\circ} 0$ Clock / Left side figuredemonstrating horseshoe fistula

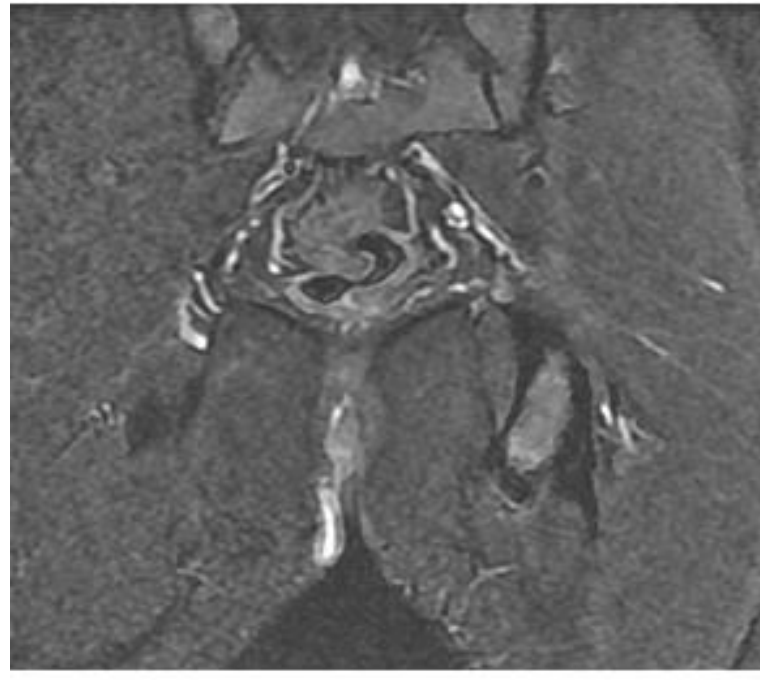

Rt side - linear longitudinal tract with no secondary ramifications -present in the intersphincteric plane

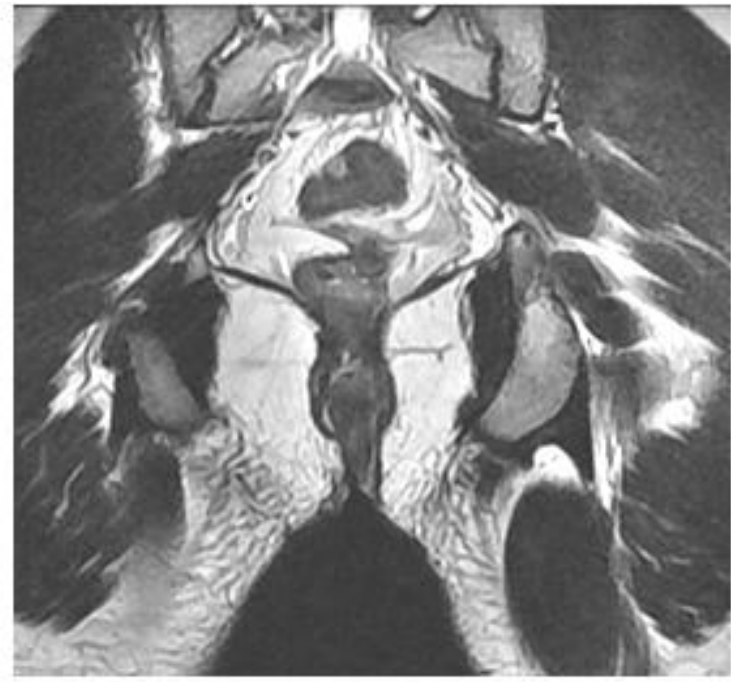

Left side - linear longitudinal with no secondary ramifications- present in the intersphincteric plane

Figure 3: Grade I - Intersphincteric fistula entering the anal canal in the midline posteriorly.
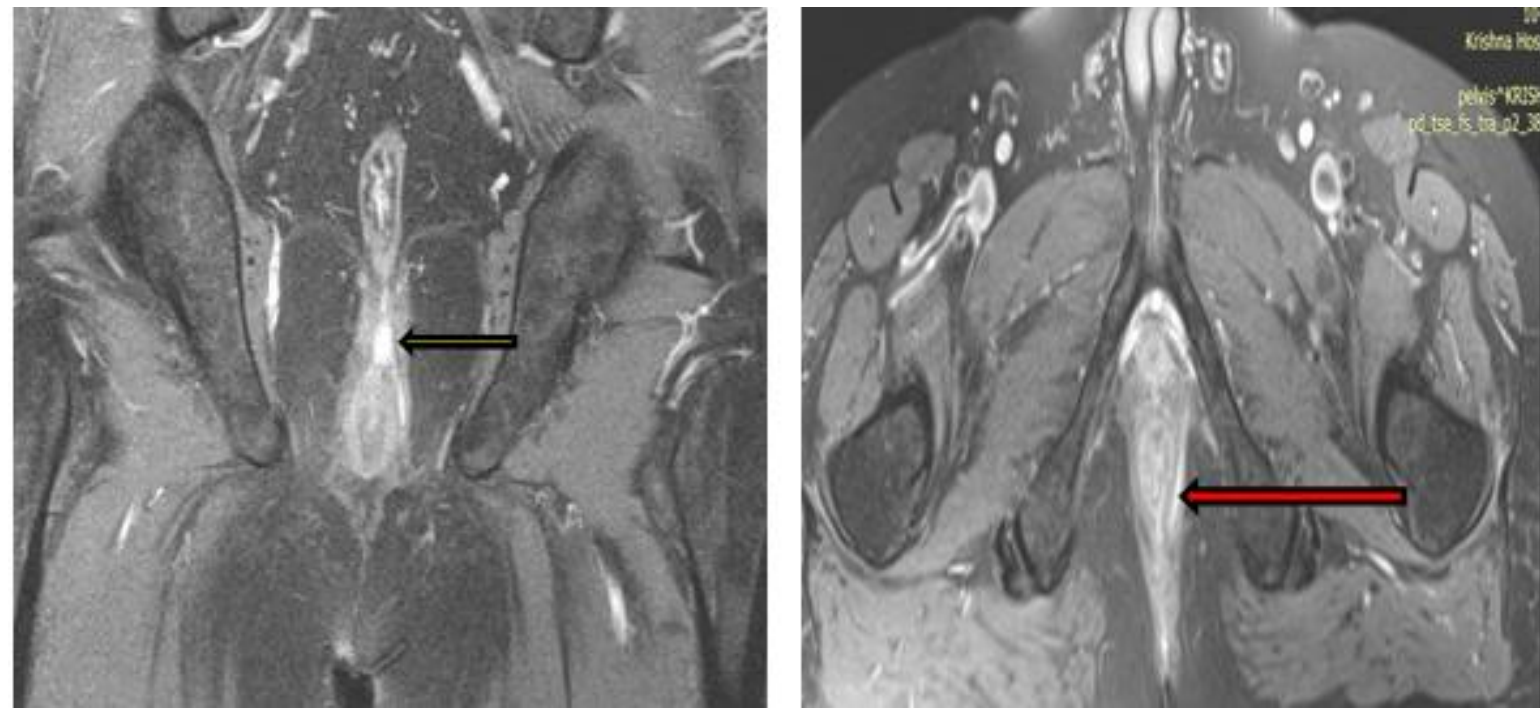

Figure 4: Grade II Intersphincteric fistula with Right-abscess (yellow arrow) \& Left-Secondary tract (red arrow).

Volume 5 Issue 1, January 2016 www.ijsr.net 


\section{International Journal of Science and Research (IJSR) \\ ISSN (Online): 2319-7064}

Index Copernicus Value (2013): 6.14 | Impact Factor (2014): 5.611

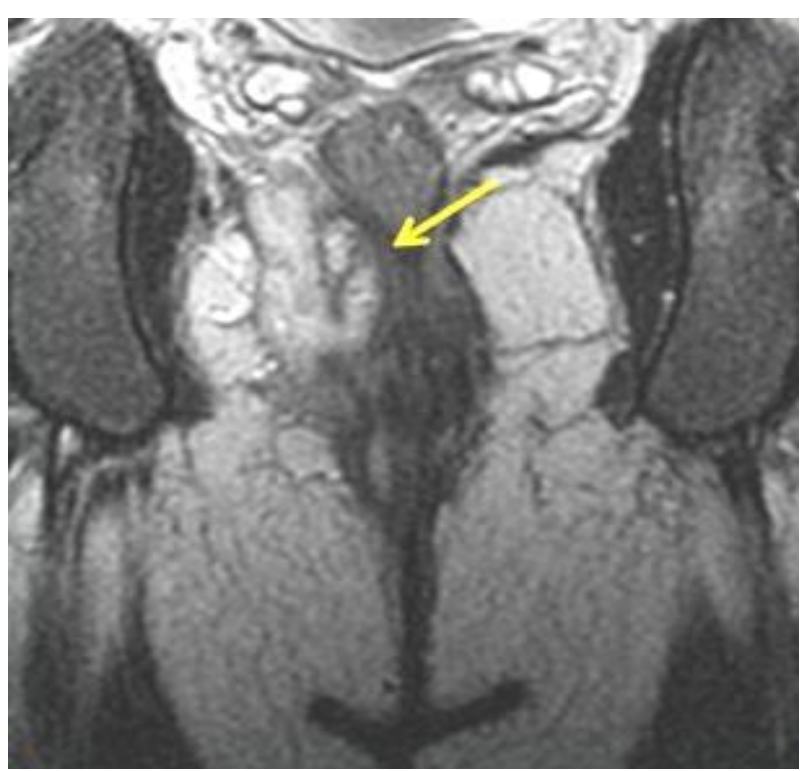

Figure 5: Grade IV - T2WFSE and T2WFSFSE Transphincteric fistula with (yellow arrow) Secondary tract and abscess formation

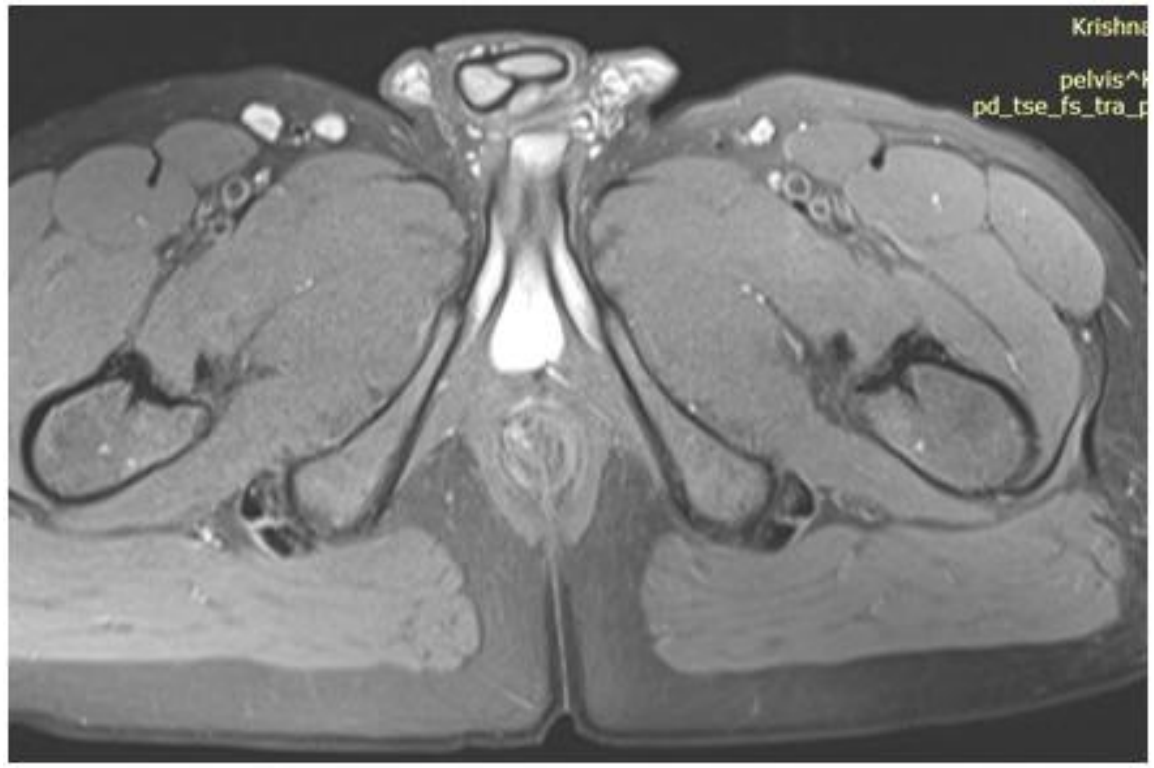

Figure 6: Grade III - MR image shows a right trans-sphincteric fistula and inflammatory change in the right ischiorectal fossa
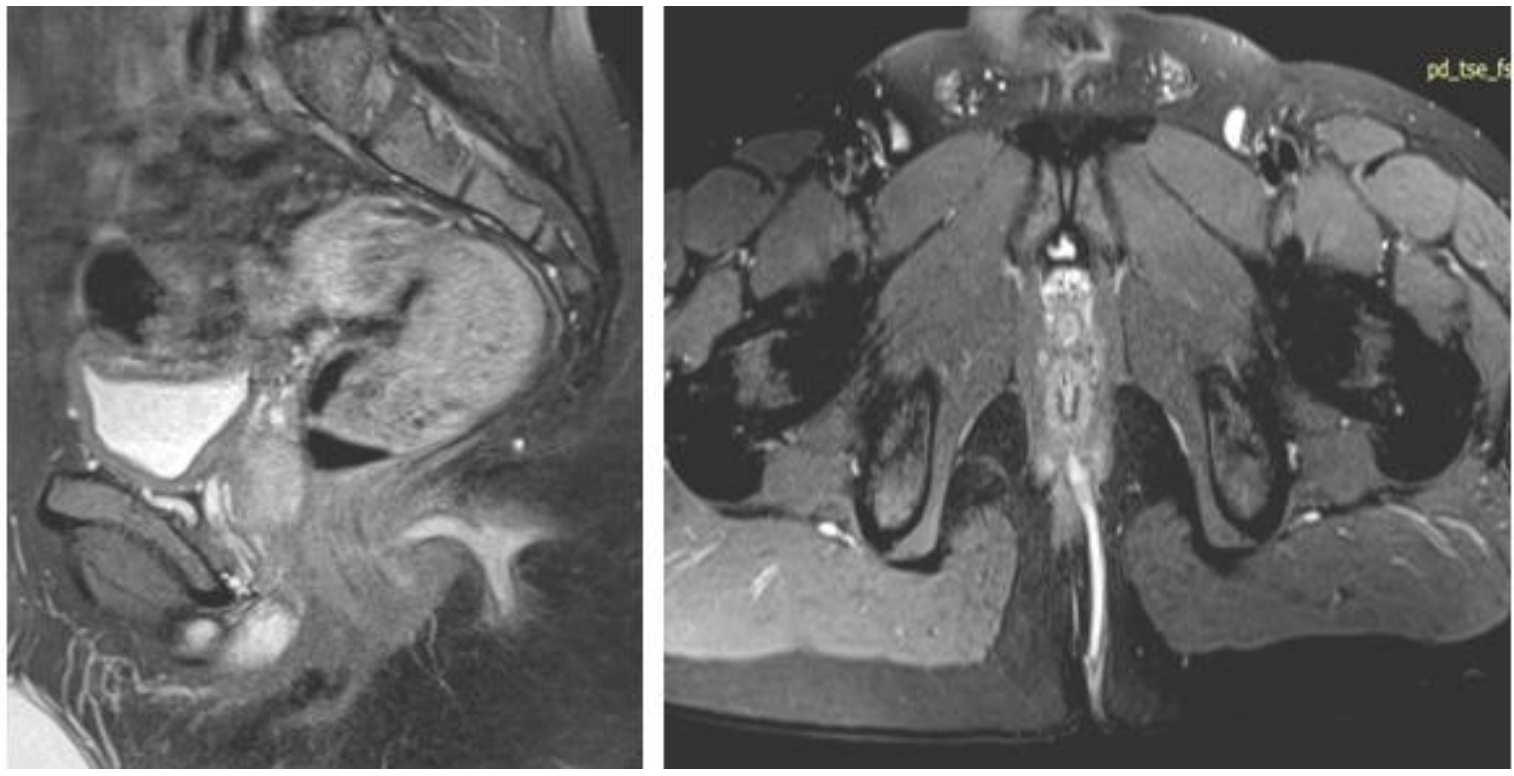

Volume 5 Issue 1, January 2016 
International Journal of Science and Research (IJSR)

ISSN (Online): 2319-7064

Index Copernicus Value (2013): 6.14 | Impact Factor (2014): 5.611

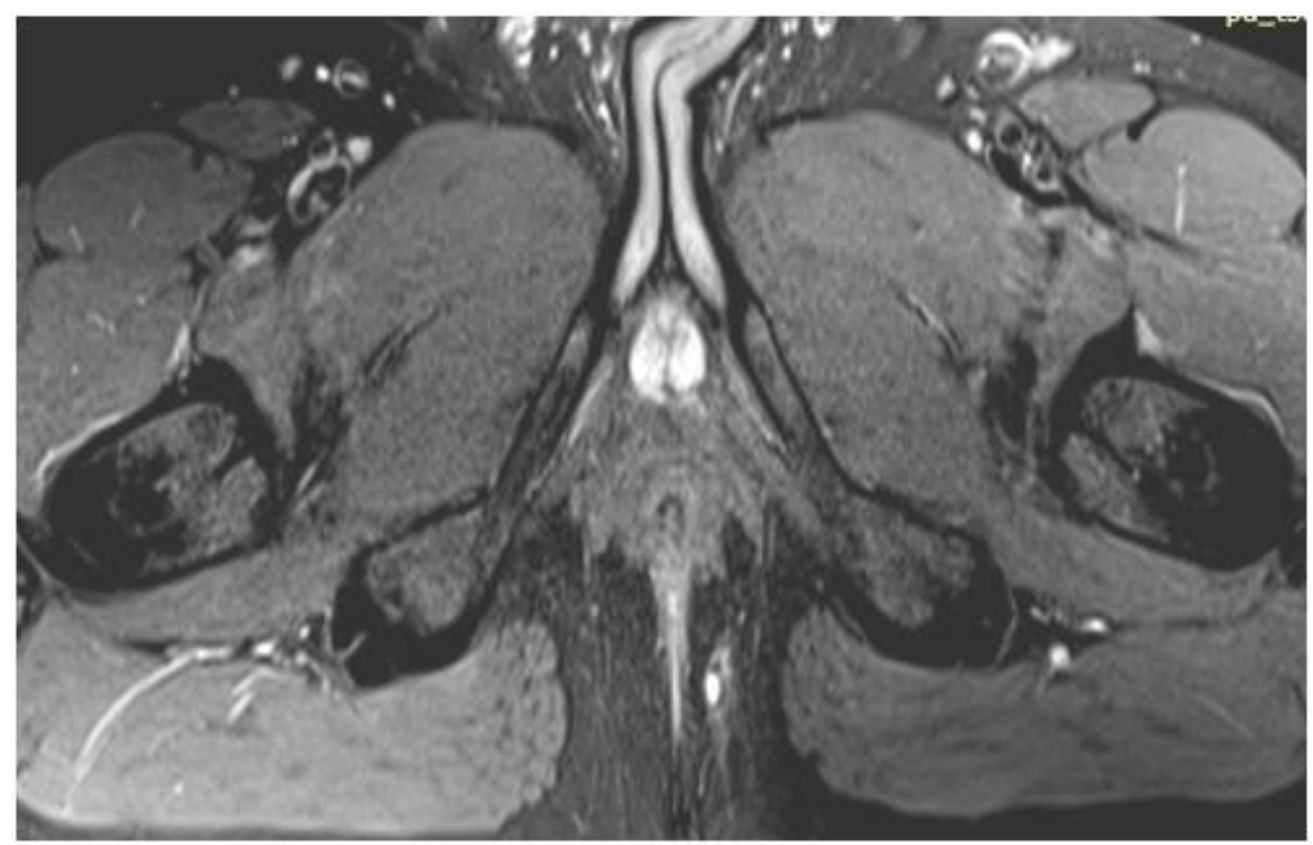

Figure 7: Grade IV - Trans-sphincteric fistula with a secondary tract in left ischiorectal fossa.
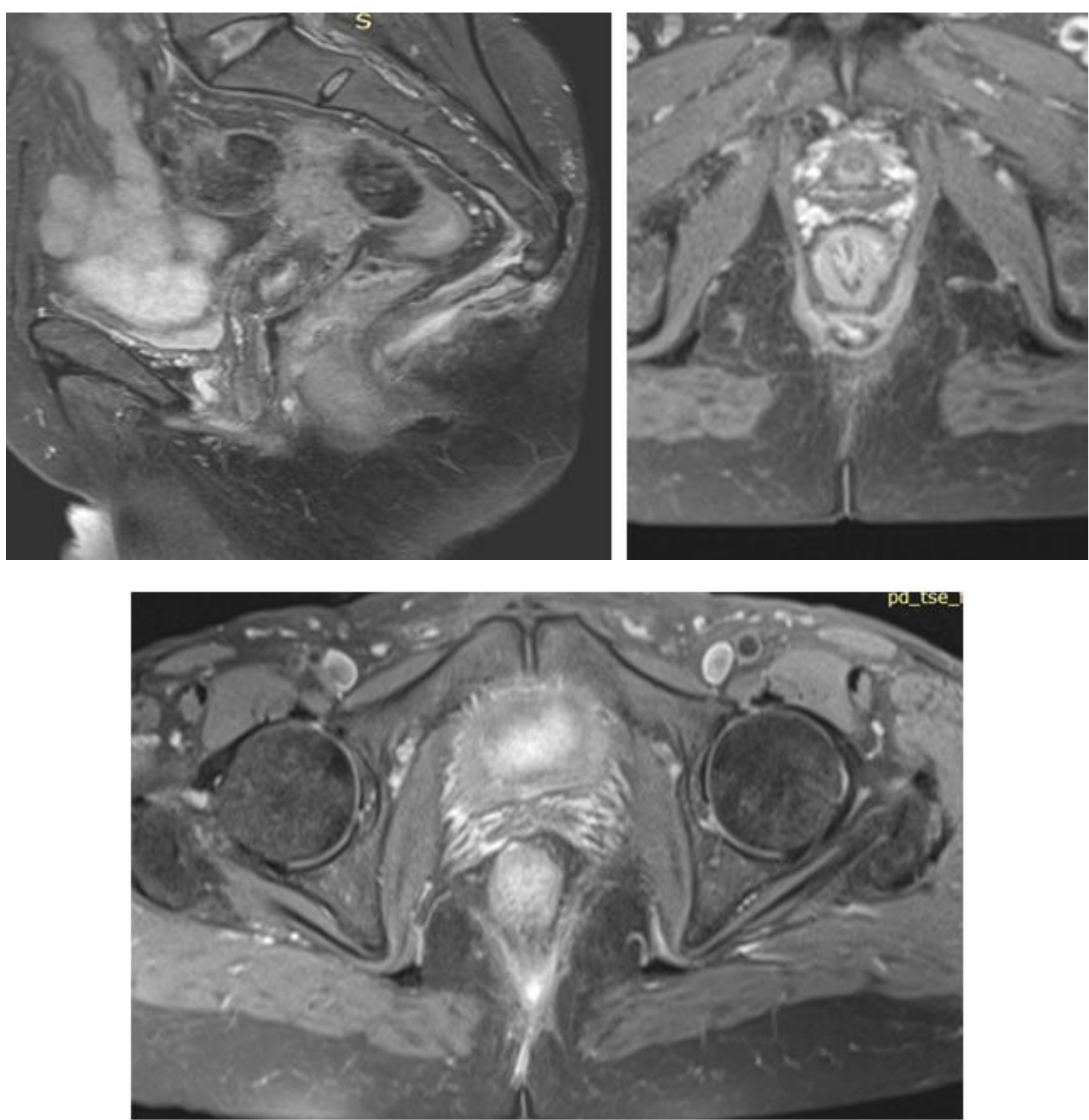

Figure 8: Grade V - Supralevator extension of fistula with secondary tracts

Volume 5 Issue 1, January 2016 www.ijsr.net 